\title{
Analysis of Vertical Market Integration for Rice Commodities between Serdang Bedagai Regency and Medan City
}

\author{
Nurhidayati Ma'rifah Sitompul', Salmiah², Sri Fajar Ayu' \\ ${ }^{1,2}$ Master of Business Agriculture Study Program on Agriculture Faculty of University of Sumatera Utara
}

Corresponding Author: Nurhidayati Ma’rifah Sitompul

\begin{abstract}
Rice is the main commodity food for Indonesian people. The majority of Indonesian people consume it on daily basis. Due to this reason, Rice has a strategic value not only to live the life of society but also to be used as a parameter of the country's economic and social stability. If the scarcity or unmet need for rice happens, it will have an impact on inflation and social turmoil. The purpose of this study was to analyze and analyze the integration of the rice market in the short and long term between the Serdang Bedagai regency and Medan city. The data used in this study is secondary data using monthly time series data from January 2014 to December 2018. Timmer's Index of Market Connection Coefficient Analysis Method is used as the analytical method to measure the shortterm and long-term market integration. This index was developed by Timmer (1987). The results showed that the market integration level of wholesale rice prices in the short term between the Serdang Bedagai regency and Medan city was low with an IMC value of 1.985> 1. There is long-term integration between the markets of the Serdang Bedagai regency and Medan city wholesalers with a coefficient value of $b 2$ of $0.713>0$. The level of market integration in the short term between the Serdang Bedagai regency and Medan city retail rice price is low with an IMC value of 2.243> 1 . There is long-term integration between the market of the Serdang Bedagai regency and Medan city retail with a coefficient of b2 of $0.463>0$.
\end{abstract}

Keywords: Market Integration, Rice, Index of Market Connection

\section{BACKGROUND}

Indonesia is an agricultural country, meaning that the agricultural sector plays an important role in the overall national economy. Agriculture in a broad sense consists of five sectors, namely food crops, plantations, animal husbandry, fisheries and forestry. Rice is the main food commodity of the Indonesian people, almost the entire population in this country consumes rice every day. This causes the rice commodity to have a very strategic value, apart from controlling the livelihoods of many people, it can also be used as a parameter of the country's economic and social stability. If there is a shortage or unfulfilled rice needs in the community, it will have an impact on inflation and social turmoil.

As the largest rice producing area in Sumatera Utara Province, Serdang Bedagai Regency has a fairly close distance to Medan City which makes Serdang Bedagai Regency the largest supplier of rice in Medan City. Perbaungan is the gateway when entering Serdang Bedagai Regency from Medan. The distance between Perbaungan and Medan City is $46.6 \mathrm{Km}$. The distance between Sei Rampah and Medan City is about $70.3 \mathrm{~km}$. The distance between Tebing Tinggi City and Medan City is about $87.8 \mathrm{~km}$. Medan City is the largest city in Sumatera Utara and is also the capital city of Sumatera Utara Province. Medan City is also included in the Metropolitan City, which has a fairly rapid population growth. The population is one of 
the direct factors that affect the demand for rice. Along with that, the need for rice is also great, which is known as a staple food. Medan City as an urban area which is the center of rice distribution in Sumatera Utara Province.

Rice prices are very important for the national economy because the price level of this important food commodity greatly affects food security, poverty levels, macroeconomic stability, and economic growth. These considerations, the stability of rice prices are one of the main indicators of the economy. Price risk for rice is relatively large because seasonal production is highly dependent on the weather, dealing with demand that is relatively constant over time and is not elastic to price changes. In order to maintain the stability and certainty of rice prices, as well as the affordability of rice prices to consumers, it is necessary to determine the highest retail price of rice. Highest Retail Price of Rice, hereinafter abbreviated as HET, is the highest selling price of packaged and/or bulk rice in people's markets, modern shops and other retail sales places.

The market plays an important role in the distribution of goods, especially agricultural products (farm products) from producers to consumers. The market is used to accommodate and distribute agricultural products from farmers (producers) to consumers. Therefore, farmers will try to market the results of their farming to markets that can accommodate the results of their farming at a price that benefits farmers. However, often the prices formed in the farmer-level market cannot keep up with price changes that occur in the consumerlevel market due to lack of market information. This will lead to greater price fluctuations and farmers to get lower prices.

Market integration or integration is one indicator of marketing efficiency, especially price efficiency. Asmarantaka (2009) states that market integration is a measure that shows how far changes in prices that occur in the reference market (markets at a higher level such as retailers) will cause changes in the follower markets (e.g. markets at the farmer level). Timmer (1986) concluded that the market structure consists of one primary market and several secondary markets. The primary market controls price formation while the secondary market responds to conditions in the primary market.

Market integration provides information on price fluctuations in one area and its impact on other areas so that it can be used as an anticipatory measure to prevent the spread of price fluctuations. By knowing the level of integration and the factors that determine it, the policies that will be implemented are expected to be implemented more effectively and achieve the desired goals. Based on the description on this background, the researcher is interested in analyzing the vertical market integration of rice commodities between Serdang Bedagai Regency and Medan City.

\section{Integrasi}

Market integration is a measure that shows the level of price movements that occur in the reference market will cause changes in the follower market. Changes in the price of apples at the farmer and retailer levels are not balanced, this indicates that price transmission between marketing agencies is still low. Inadequate and unequal price information between farmers and retailers will lead to information asymmetry resulting in market failure, while also indicating that the market is not integrated (Zunaidah, 2015). According to Heytens (1986), two markets are said to be integrated if price changes in one market are manifested in the same price response in other markets.

Vertical market integration is used to see the level of closeness of the relationship between a marketing agency and other marketing institutions in a marketing chain. Vertical market integration is influenced by the equitable distribution of price information to all marketing institutions (producers-wholesale-retail-consumers). If the information is not perfectly 
disseminated to consumers, the prices formed in the market do not indicate a good vertical market integration (Ariyani, 2012).

\section{Kerangka Pemikiran}

The relationship between the Market in Serdang Bedagai Regency and the Wholesale Market and Retail Market in the city of Medan will form a vertical market integration, because of the market relationship between the Regency level market and the Provincial level market. Then it will be seen the integration of the Serdang Bedagai Regency market with the Wholesale Market and Retail Market in Medan City vertically in the short and long term.

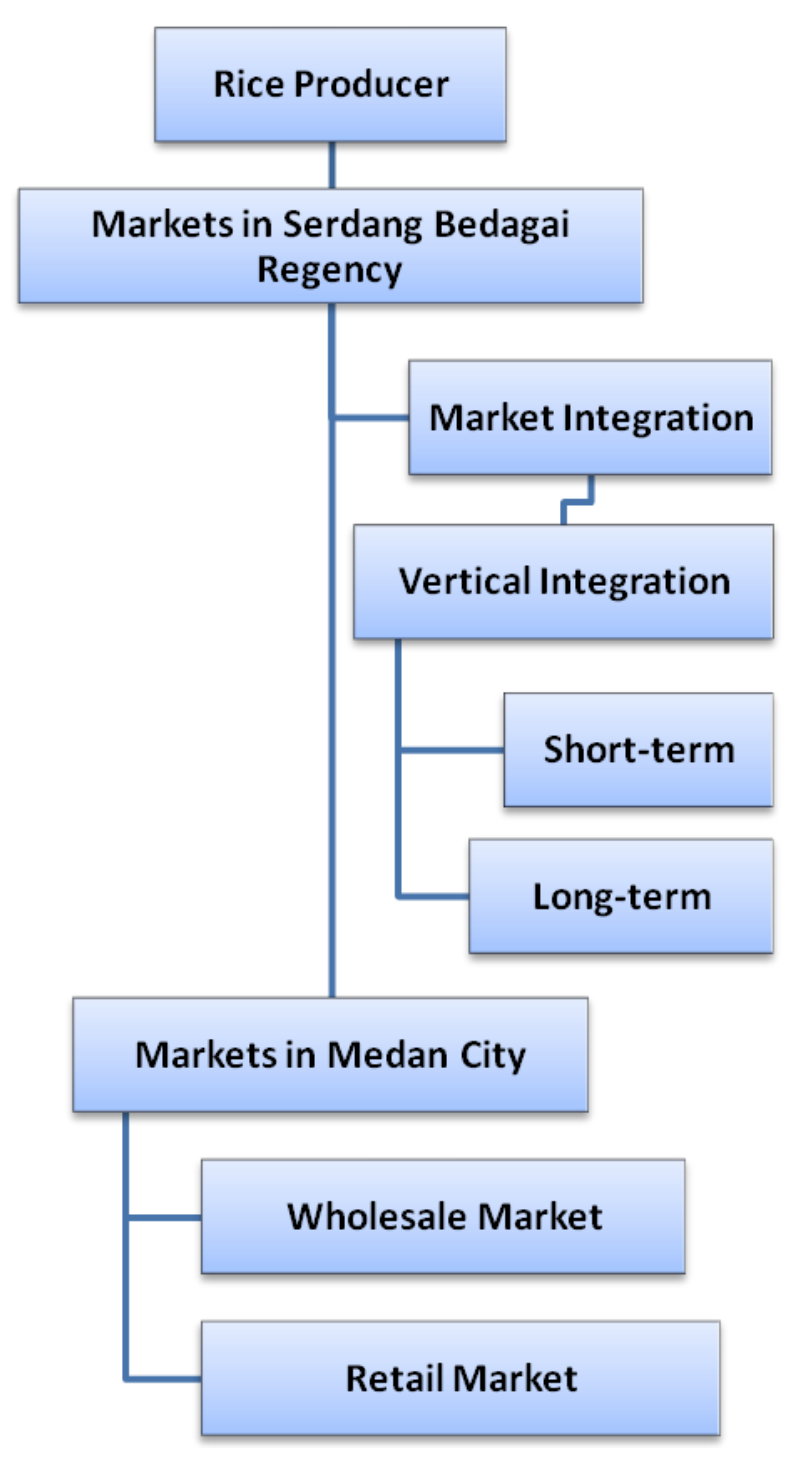

Figure 1. Conceptual Framework

\section{Research Hypothesis}

The level of vertical market integration of rice commodities in the short and long term between the market in Serdang Bedagai Regency and the market in Medan City is high.

\section{RESEARCH METHODS}

This research was conducted in Serdang Bedagai Regency, Sumatera Utara with the consideration that Serdang Bedagai Regency is one of the centers of rice production in Sumatera Utara. To analyze market integration, the data used are monthly time series data from January 2014 to December 2018 which includes data on rice prices in Serdang Bedagai Regency, wholesale price data and data on retail prices of rice in markets in Medan city, and rice production data in Serdang Bedagai Regency (2014-2018). Secondary data was obtained from several related agencies such as the Agriculture Service of Serdang Bedagai Regency, the Department of Food Crops and Horticulture of Sumatera Utara Province, the Central Bureau of Statistics of Serdang Bedagai Regency, the Central Statistics Agency of Sumatera Utara Province, and the literature that supports the research.

To measure short-term and longterm market integration using the Timmer's Index of Market Connection Coefficient Analysis Method developed by Timmer (1987). This method concludes that the market structure consists of one primary market and several secondary markets. The primary market controls price formation while the secondary market responds to conditions in the primary market. To show the effect of the past prices of the district market and the past prices of the reference market on the formation of producer prices in the retail market at a certain time, the Index of Market Connection (IMC) is used. 


\section{RESULTS AND DISCUSSION}

Changes in rice prices in the wholesale market and retail market in Medan City due to changes in rice prices that occurred in the Serdang Bedagai Regency market

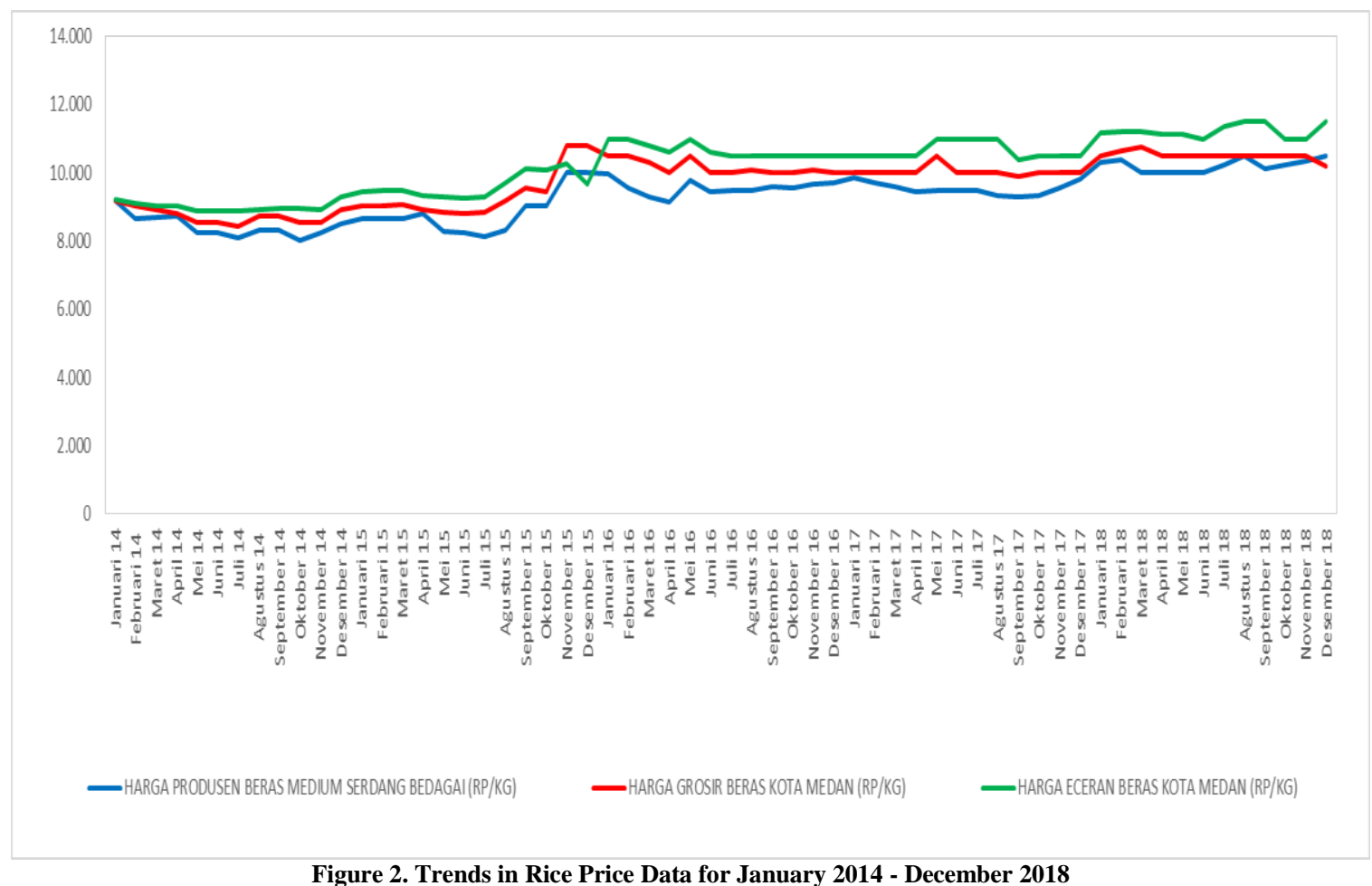

Figure 2. Trends in Rice Price Data for January 2014 - December 2018

Based on the results of statistical analysis, the highest selling price of rice that has ever occurred at the farmer level is around Rp. 10,500 and the lowest price experienced by farmers is Rp. 9,313. At the wholesaler level, the highest price ever received was Rp. 10,786 and the lowest price was Rp. 8,450. At the retailer level, the highest price ever experienced was $\mathrm{Rp}$. 11,500 and the lowest price ever experienced was Rp. 8,870.

The average selling price of rice from 2014 to 2018 at the farm level was in the range of $\mathrm{Rp} .9,313$ per $\mathrm{kg}$, while at the wholesaler and retailer level, the average selling price of rice was in the range of $\mathrm{Rp}$. 9,761 and Rp. 10,236, respectively per $\mathrm{kg}$.
Vertical market integration of rice commodity in the short and long term between the market in Medium Bedagai Regency and the market in Medan City 1. Serdang Bedagai Regency Market with Wholesale Rice Prices Medan City Market

Analysis of market integration (market integration) in this study was conducted to determine how the influence of wholesale rice price formation in Medan City on rice prices in the Serdang Bedagai Regency market. This test is carried out using IMC (Index of Market Connection) analysis through multiple linear regression testing.

Table 1. Wholesale Rice Autocorrelation Test

Model Summary ${ }^{b}$

\begin{tabular}{|c|c|c|c|c|c|}
\hline Model & $\mathbf{R}$ & R Square & Adjusted R Square & Std. Error of the Estimate & Durbin-Watson \\
\hline 1 & $.967^{\mathrm{a}}$ & .935 & .931 & 187.950 & 1.736 \\
\hline \multicolumn{6}{|c|}{ a. Predictors: (Constant), Pr-LPr, LPf, LPr } \\
\hline \multicolumn{4}{|c|}{ b. Dependent Variable: Pf } & & \\
\hline
\end{tabular}

The test results of multiple linear regression analysis on rice prices in the Serdang Bedagai Regency market and
Medan City wholesale rice prices have a good coefficient of determination (R2) of $93.50 \%$, meaning that the predictor 
variables in the model are able to explain as much as $93.50 \%$ of variations (diversity). ) on the formation of rice prices in the Serdang Bedagai Regency market and 6.5\% is explained by variables outside the model such as the amount of supply from other regions, rainfall, planting time, harvest time and the amount of production.

Table 2 Results of Market Integration Analysis of Rice Prices in Serdang Bedagai Regency with Wholesale Rice Prices in Medan City

\begin{tabular}{|c|c|c|c|c|}
\hline Description & Coefficient & T-count & P-Value & Standard Error \\
\hline b1 (rice price in Serdang Bedagai Regency market on t-1) & 0.665 & 6.054 & 0.000 & 0.110 \\
\hline b2 (difference in wholesale rice prices in Medan City in period $t$ and period $t-1$ ) & 0.713 & 7.608 & 0.000 & 0.094 \\
\hline b3 (Medan wholesale price of rice at $\mathrm{t}-1$ ) & 0.335 & 3.150 & 0.003 & 0.106 \\
\hline \multicolumn{5}{|l|}{ F-statistik $=262,944$} \\
\hline \multicolumn{5}{|l|}{ R-Square $=0,935$} \\
\hline $\mathrm{IMC}=1,985$ & & & & \\
\hline
\end{tabular}

Based on the simultaneous test $(\mathrm{F}$ test) that the predictors used in the market model of Serdang Bedagai Regency and Medan City wholesale rice prices together have a significant effect on the 95 percent confidence level, this is shown by the value of $\mathrm{f}$-count $>$ f-table $(\alpha=0.05 ;$ df $1=\mathrm{k}-1$; df2=nk-1) with a value of 262,944 > 3.16.

The results of multiple regression analysis show that the results of the partial test ( $t$ test), the estimator coefficient b1 (the predictor variable for rice prices in the Serdang Bedagai Regency market last month) significantly affect price formation in the Serdang Bedagai Regency market this month at a confidence interval of 95 percent.

The results of the t-test obtained are greater than t-table (1.67) of 6.054 (t-count $>\mathrm{t}$-table), this is reinforced by a $\mathrm{p}$-value of 0.000 which is smaller than the critical value of $0.05(0.000<0.05)$. The estimator coefficient b2 (predictor variable for the difference in wholesale rice prices in Medan City in period $t$ and period $t-1$ ) was found to have a significant effect on price formation in the Serdang Bedagai Regency market this month at a confidence interval of 95 percent.

The results of the t-test obtained are 7.608 which is greater than t-table 1.67 (tcount $>\mathrm{t}$-table) which is then supported by a p-value of 0.000 which is smaller than the critical value of $0.05 \quad(0.000<0.05)$. Meanwhile, the estimator coefficient b3 (predictor variable for wholesale rice prices in Medan City at t-1) was found to have a significant effect on price formation in the
Serdang Bedagai Regency market this month at a confidence interval of 95 percent.

The results of the t-test obtained are 3.150 which is greater than t-table $1.67(\mathrm{t}-$ count $>\mathrm{t}$-table) which is then supported by a $\mathrm{p}$-value of 0.003 which is smaller than the critical value of $0.05(0.003<0.05)$. Shortterm market integration shows how price changes based on time in the reference market (the wholesale price of rice in Medan City) are directly transmitted to the local market (the Serdang Bedagai Regency market).

Thus, the IMC calculation can be carried out as follows:

$$
\mathbf{I M C}=\frac{b 1}{b 3}=\frac{0,665}{0,335}=\mathbf{1 , 9 8 5}
$$

Based on the calculation results, the IMC value is 1.985. The IMC value of $1.985>1$ means that the level of market integration in the short term between the Serdang Bedagai Regency Market and the Medan City wholesale rice price is low. This shows that information about changes in wholesale rice prices in Medan City is not fully transmitted to the Serdang Bedagai Regency Market.

Market integration in the long term is the link between the local market (Market of Serdang Bedagai Regency) and the reference market (Wholesale of Medan City) which is represented by the market integration index. Long-term integration is represented by the coefficient b2 (price margin of this month with last month). The value of the coefficient $b 2$ from the equation 
shows the percentage of price changes in the local market due to price changes in the reference market. A market is integrated in the long run if the coefficient b2 is close to 1. Meanwhile, if the value is $b 2 \leq 0$, it can be said that the market is isolated or the market moves independently. The test results show that the value of the coefficient b2 is 0.713 $(>0)$. This means that there is a long-term integration between the Serdang Bedagai Regency market and Medan City wholesalers.

\section{Serdang Bedagai Regency Market with Retail Rice Prices Medan City Market}

Table 3 Retail Rice Autocorrelation Test Model Summaryb

\begin{tabular}{|l|l|l|l|l|l|}
\hline Model & R & R Square & Adjusted R Square & Std. Error of the Estimate & Durbin-Watson \\
\hline 1 & .949 a & .900 & .895 & 232.389 & 1.657 \\
\hline \multicolumn{2}{|l|}{ a. Predictors: (Constant), Pr-LPr, LPf, LPr } & & \\
\hline \multicolumn{2}{|l|}{ b. Dependent Variable: Pf } & & \\
\hline
\end{tabular}

The Durbin Watson value obtained in this study was 1,657 , while the DL and DU values based on the provision table were 1,479 and 1,689 , respectively. Acceptance rate was carried out with DW<4-DU $(1.658<2.521)$. Thus, it can be concluded that there is no autocorrelation of the research data used.

The test results of multiple linear regression analysis on the price of rice in the Serdang Bedagai Regency market and the retail price of Medan City have a good coefficient of determination (R2) of $90.00 \%$, meaning that the predictor variables in the model are able to explain as much as $93.50 \%$ of the variation (diversity), on the formation of rice prices in the Serdang Bedagai Regency market and $10.00 \%$ is explained by variables outside the model such as the amount of supply from other regions, rainfall, planting time, harvest time and the amount of production.

Table 4. Results of Market Integration Analysis of Rice Prices in Serdang Bedagai Regency with Retail Rice Prices in Medan City

\begin{tabular}{|l|l|l|l|l|}
\hline Description & Coefficient & T-count & P-Value & Standard Error \\
\hline b1 (rice price in Serdang Bedagai Regency market on t-1) & 0,646 & 6,372 & 0,000 & 0,101 \\
\hline $\begin{array}{l}\text { b2 (the difference between the retail price of rice in Medan City in } \\
\text { period t and period t-1) }\end{array}$ & 0,463 & 4,167 & 0,000 & 0,111 \\
\hline b3 (Medan retail price of rice at t-1) & 0,288 & 3,353 & 0,001 & 0,086 \\
\hline F-statistik=165,654 & & & & \\
\hline R-Square $=0,900$ & & & & \\
\hline IMC $=2,243$ & & &
\end{tabular}

Based on the simultaneous test $(\mathrm{F}$ test) that the predictors used in the market model of Serdang Bedagai Regency and the retail price of rice in Medan City together have a significant effect on the 95 percent confidence level, this is shown by the value of f-count > f-table $(\alpha=0.05 ;$ df $1=\mathrm{k}-1$; df $2=$ nk-1) with a value of $165.654>3.16$.

The results of multiple regression analysis show that the results of the partial test ( $t$ test), the estimator coefficient b1 (the predictor variable for rice prices in the Serdang Bedagai Regency market last month) significantly affect price formation in the Serdang Bedagai Regency market this month at a confidence interval of 95 percent.
The results of the t-test obtained are greater than t-table (1.67) of 6.372 (t-count $>\mathrm{t}$-table), this is reinforced by a p-value of 0.000 which is smaller than the critical value of $0.05(0.000<0.05)$. The estimator coefficient b2 (predictor variable for the difference in retail rice prices in Medan City in period $t$ and period $t-1$ ) was found to have a significant effect on price formation in the Serdang Bedagai Regency market this month at a confidence interval of 95 percent.

The results of the t-test obtained are 4.167 which is greater than t-table 1.67 (tcount $>\mathrm{t}$-table) which is then supported by a p-value of 0.000 which is smaller than the critical value of $0.05 \quad(0.000<0.05)$. Meanwhile, the estimator coefficient b3 was 
found to have a significant effect on price formation in the Serdang Bedagai Regency market this month at a 95 percent confidence interval.

The results of the t-test obtained are 3.353 , which is greater than $\mathrm{t}$-table $1.67(\mathrm{t}-$ count $>$ t-table), which is then supported by a p-value of 0.001 which is smaller than the critical value of $0.05(0.001<0.05)$. Shortterm market integration shows how price changes based on time in the reference market (the retail price of rice in Medan City) are directly transmitted to the local market (the Serdang Bedagai Regency market).

Thus, the IMC calculation can be carried out as follows:

$$
\text { IMC }=\frac{b 1}{b 3}=\frac{0,646}{0,288}=\mathbf{2 , 2 4 3}
$$

Based on the calculation results, the IMC value is 2.243 . The IMC value of $2.243>1$ means that the level of market integration in the short term between the Serdang Bedagai Regency Market and the retail price of rice in Medan City is low. This shows that information about changes in retail rice prices in Medan City is not fully transmitted to the Serdang Bedagai Regency Market.

Market integration in the long term is the link between the local market (Pasar Kabupaten Serdang Bedagai) and the reference market (retail market in Medan City) which is represented by the market integration index. Long-term integration is represented by the coefficient b2 (price margin of this month with last month). The test results show that the coefficient of $b 2$ is $0.463(>0)$. This means that there is a longterm integration between the Serdang Bedagai Regency market and the Medan City retail rice price.

\section{CONCLUSION}

The level of market cohesiveness in the short term between the Serdang Bedagai Regency Market at the wholesale rice price in Medan City and the retail rice price in
Medan City is low. The level of market integration in the long term between the Serdang Bedagai Regency market with the wholesale market in Medan City and the retail market in Medan City is high/integrated.

\section{Acknowledgement: None}

Conflict of Interest: None

\section{Source of Funding: None}

\section{REFERENCES}

1. Amang, Beddu dan M. Husein Sawit. 1999. Kebijakan Beras dan Pangan Nasional: Pelajaran Orde Baru dan Orde Reformasi. Institut Pertanian Bogor.

2. Amikuzuno, J. dan K. Ogundari. (April, 2012). The Contribution of Agricultural Economics to Price Transmission Analysis and Market Policy in Sub-Sahara Africa: What Does the Literature Say? Paper presented at the $86^{\text {th }}$ Annual Conference of the Agricultural Economics Society, United Kingdom.

3. Ariyani, D, (2012), "Integrasi Vertikal Pasar Produsen Gabah dengan Pasar Ritel Beras di Indonesia", Jurnal Manajemen Teknologi, Vol. 11 (2), hal. 225-238

4. Asmarantaka, R.W. 2009. Pemasaran Produk-produk Pertanian. Bunga Rampai Agribisnis: Seri Pemasaran. IPB Press, Bogor.

5. Barrett and Emelly. 2005. Agricultural markets in developing countries. The New Palgrave Dictionary of Economics, 2nd Edition. Cornell University.

6. Heytens, P.J. 1986. Testing Market Integration. Food Research Institute Studies, XX (1).

7. Ismet, M, (2010), Pelajaran dari Krisis Pangan Dunia 2008, Arsitektur Kebijakan Beras di Era Baru, PT Penerbit IPB Press, Bogor.

8. https://www.wartaekonomi.co.id/read16709 5/2017-sumut-surplus-padi-hingga-17-jutaton.html

9. Meyer, J. dan S. von Cramon-Taubadel (2004). Asymmetric Price Transmission: A Survey. Journal of Agricultural Economics, Vol 55, No 3, 581-611 
Nurhidayati Ma'rifah Sitompul et.al. Analysis of vertical market integration for rice commodities between Serdang Bedagai Regency and Medan City.

10. Ravallion M. 1986. Testing market integration. American Journal of Agricultural Economics. 68:102-09

11. Soekartawi. 1999. Agribisnis Teori dan Aplikasi. PT. Raja Grafindo Persada. Jakarta.

12. Sumanda, Ressi Nata. 2014. Permintaan, Penawaran dan Keseimbangan Pasar. Online.http://ressinatasumanda.blogspot.co m. Diakses 10/01/2020

13. Supari. 2001. Manajemen Produksi dan Operasi Agribisnis Hortikultura. Seri Praktek Ciputri Hijau. PT. Elex Media Komputindo. Jakarta.
14. Timmer PC. 1986. Getting Prices Right The Scope and Limits of Agricultural Price Policy. Ithaca, NY: Cornell University Press

15. Tomek W. Robinson KL. 1990. Agricultural Product Prices. Third Edition. Cornell University Press. Ithaca.

How to cite this article: Nurhidayati Ma'rifah Sitompul, Salmiah, Ayu SF. Analysis of vertical market integration for rice commodities between Serdang Bedagai Regency and Medan City. International Journal of Research and Review. 2021; 8(6): 332-339. DOI: https://doi.org/10. 52403/ijrr.20210642 